\title{
Carbon Sequestration Potential of Forest Invasive Species: A Case Study with Acacia dealbata Link
}

\author{
Leonel J. R. Nunes ${ }^{1, *(\mathbb{D}}$, Mauro A. M. Raposo ${ }^{2}\left(\mathbb{D}\right.$, Catarina I. R. Meireles ${ }^{2}\left(\mathbb{D}\right.$, Carlos J. Pinto Gomes ${ }^{2,3}$ \\ and Nuno M. C. Almeida Ribeiro ${ }^{4,5}$ i \\ 1 PROMETHEUS-Unidade de Investigação em Materiais, Energia e Ambiente para a Sustentabilidade, Escola \\ Superior Agrária, Instituto Politécnico de Viana do Castelo, Rua da Escola Industrial e Comercial de \\ Nun'Alvares, 4900-347 Viana do Castelo, Portugal \\ 2 MED-Mediterranean Institute for Agriculture, Environment and Development, Pólo da Mitra, Universidade \\ de Évora, 7006-554 Évora, Portugal; mraposo@uevora.pt (M.A.M.R.); cmeireles@uevora.pt (C.I.R.M.); \\ cpgomes@uevora.pt (C.J.P.G.) \\ 3 Departamento da Paisagem, Ambiente e Ordenamento, Universidade de Évora, 7000-671 Évora, Portugal \\ 4 ICT-Instituto de Ciências da Terra, Universidade de Évora, Rua Romão Ramalho, 59, \\ 7002-554 Évora, Portugal; nmcar@uevora.pt \\ 5 Departamento de Fitotecnia, Universidade de Évora, 7000-083 Évora, Portugal \\ * Correspondence: leonelnunes@esa.ipvc.pt; Tel.: +351-258-909-740
}

check for

updates

Citation: Nunes, L.J.R.; Raposo, M.A.M.; Meireles, C.I.R.; Pinto

Gomes, C.J.; Almeida Ribeiro, N.M.C.

Carbon Sequestration Potential of

Forest Invasive Species: A Case Study with Acacia dealbata Link. Resources 2021, 10, 51. https://doi.org/ $10.3390 /$ resources 10050051

Academic Editor:

Witold-Roger Poganietz

Received: 9 April 2021

Accepted: 13 May 2021

Published: 17 May 2021

Publisher's Note: MDPI stays neutral with regard to jurisdictional claims in published maps and institutional affiliations.

Copyright: (c) 2021 by the authors. Licensee MDPI, Basel, Switzerland. This article is an open access article distributed under the terms and conditions of the Creative Commons Attribution (CC BY) license (https:// creativecommons.org/licenses/by/ $4.0 /)$.

\begin{abstract}
Biological invasions are of complex solution, consuming resources for their control and eradication. However, in many of the documented processes that are available, this is an attempt with no solution in sight. The possibility of increasing the pressure over these species while creating value chains has been presented as a method for ensuring the sustainability of their control and eradication processes. In the case of invasive forest species in Portugal, such as Acacia dealbata Link, this control is becoming increasingly important. In addition to the negative impacts on biodiversity, the proliferation of this species has economic implications due to its competition with forest production species such as Pinus pinaster Aiton and Eucalyptus globulus Labill. Another critical aspect to be considered is the increase of the risk of rural fires, which is enhanced by the accumulation of low-value biomass around production forests. In this work, the possibility of using this species as a vehicle for the capture and sequestration of carbon in the medium and long-term was evaluated from a perspective of providing ecosystem services as a measure to mitigate climate change. However, due to its highly heliophilous character, it was found that the growth capacity of this species is rapidly conditioned by the position of each tree within a stand, not being able to maintain that capacity in the medium and long term.
\end{abstract}

Keywords: Acacia dealbata; energy recovery; carbon capture and sequestration; annual rate of carbon sequestration (ARCS); ecosystem services

\section{Introduction}

Invasive forest species pose a permanent threat to the biodiversity of ecosystems, competing directly with native species for access to nutrients, water, space, and access to sunlight [1]. Due to their resilient nature, these species can override native species, gaining area, often taking advantage of external occurrences such as rural fires, since many of these species are pyrophytes [2]. This characteristic, which allows these species to benefit from rural fires, is easily explained if associated with another characteristic, mainly being heliophiles [3]. After being activated by the passage of the fire, which eliminates the vegetation cover, seeds can germinate without the competition of the shade caused by other plants, allowing access to sunlight and, thus, developing quickly [4]. Additionally to this germinative explosion, some plants may still sprout, depending on the fire severity, since roots often remain alive and can restart the growth process [5]. 
However, this competition for resources between exotic and native species does not affect only the biodiversity of natural ecosystems [6]. The invasion by exotic forest-type species has a direct and negative impact on production forests. These production species are used for a specific purpose, regardless of being exotic or not, and will suffer direct competition from these invasive species if their occurrence is not controlled by the forest managers [7]. For example, a production forest dedicated to eucalyptus for the pulp and paper industry can suffer from an acacia infestation, especially in the neighboring areas or in the areas of recent cuts, where acacias can have access to the sunlight, water, and soil nutrients. After being installed, the presence of these species can affect the productivity of other species with their allelopathic behavior [8]. Many examples of this competition are described and found in the available literature [9-11].

In Portugal, biological invasions have been studied for a long time and has been the subject of many studies [12]. In these studies are described several approaches, from the characterization of the occurrences, to the analysis of the biological cycles, or even to their control by diverse methods [13]. However, the invasion by forest species, in recent years, acquired an unusual role, being associated with the occurrence of rural fires [14].

This resilience, associated with the increased probability of rural fires and to the shortening of the occurrence periods, as a direct cause of the climatic changes in the regions of Mediterranean climate, has been identified as the most significant factor that contributes to the dispersion of invasive forest species, such as those of the genus Acacia [15]. In Portugal, despite several species of this genus already being registered, such as Acacia melanoxylon R. Br., Acacia longifolia (Andrews) Willd., and Acacia saligna (Labill.) H.L. Wendl., the one that has covered the largest area is Acacia dealbata Link. [16]. This species has increasingly developed in recent years, with a growth line beginning to trend upward, as shown in Figure 1. The area occupied until 1975 did not exceed 2500 ha. However, in the mid-1980s, the area occupied by A. dealbata started to increase. A relation can be found between the increase in the A. dealbata area and the number of events of rural fires. From the analysis of the historical data of rural fires, the tendency is toward a decrease in the number of events in the immediately following years, most likely due to the elimination of the fuel load and because it corresponds to the biomass recovering period. However, a deeper analysis may indicate a decrease in this recovery time of the aboveground biomass, especially if this type of species, such as A. dealbata, starts to be dominant in certain areas, increasing the risk of incidence of rural fires.

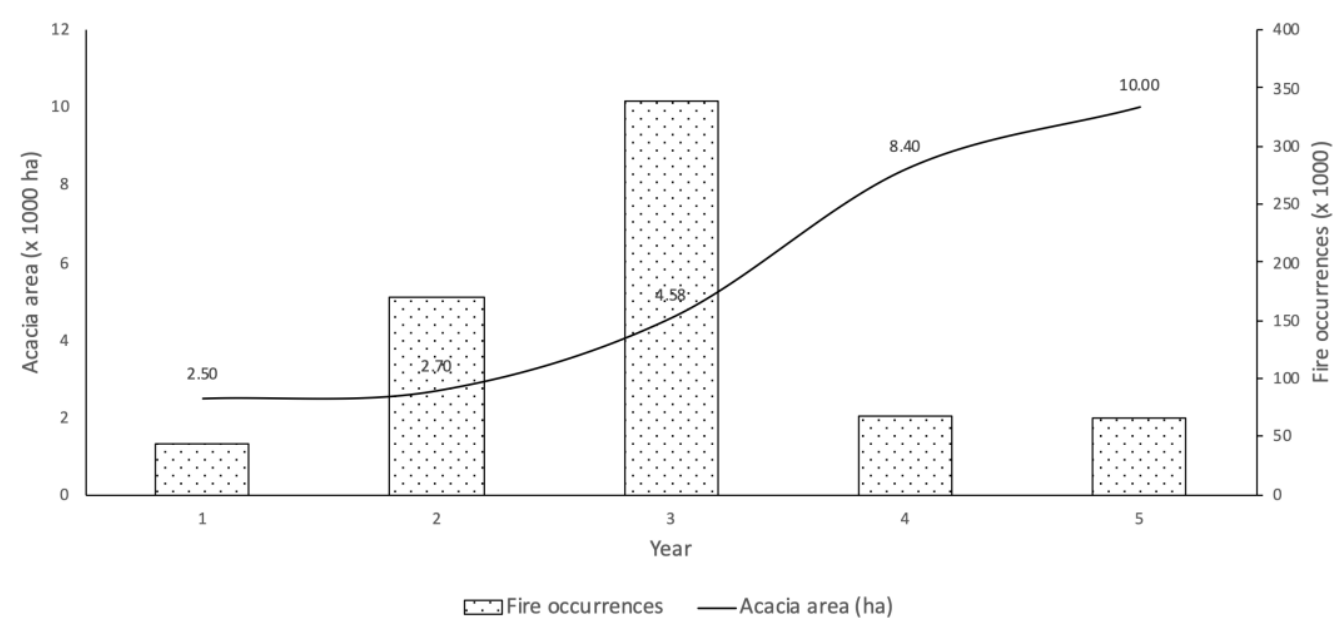

Figure 1. Increase in the area occupied by $A$. dealbata and its relationship with the number of occurrences of rural fires (adapted from [17-19]). The value of the occupied area for 2020 is only indicative, following a growth trend inflected in 2015 , curbing a trend that pointed toward exponentiality, most likely due to the control measures implemented in many parts of the country. 
A. dealbata, another species of the genus Acacia, and other forest-type invasive species are most likely undergoing a naturalization process, becoming adapted to the edaphoclimatic conditions of the area over time [20]. This naturalization implies that eradicating these species is becoming a long process given the inability to counter the germination rate of seeds already existing in the soil [21]. For different reasons, the same already happened with other species, such as Eucalyptus globulus Labill., which today thrives throughout the national territory in productive, planted forests and in spontaneous stands, which are currently part of the landscape [22].

While being a concern, these species such as A. dealbata become part of ecosystems, with adaptations of both ecosystems and the species to the new situation, leading to the organization of forest space and the services it provides [23,24]. Ecosystem services shall be reconsidered to include these species and the positive role they may eventually play since the negative impacts are already widely recognized [25]. Aspects such as biomass production for wood and fuels (wood pellets, charcoal, torrefied biomass, and chips, among others) lead to constant pressure on the now-defined resource, contributing to the control of its expansion, reducing negative impacts. Simultaneously, creating these value chains directly contributes to the minimization of the costs of control operations, giving some sustainability to the process [26].

Invasive species can contribute positively in other ways, for example, through carbon sequestration, contributing to the mitigation of climate change [27]. Species such as $A$. dealbata can play an essential role in capturing and fixing carbon since it is a fast-growing species capable of quickly removing significant amounts of carbon from the atmosphere in the form of $\mathrm{CO}_{2}$ [28]. The creation of a sequence of operations including the control of invasive species that lead to a process of carbon concentration, such as carbonization or any other thermochemical conversion process, with subsequent sequestration of these materials in soils or landfills created for the purpose, falls under the classification of negative emission technologies (NET), according to the 2018 Special Report on the impacts of $1.5^{\circ} \mathrm{C}$ global warming by the Intergovernmental Panel on Climate Change (IPCC) [29].

The objective of this investigation was to analyze the potential for carbon sequestration by $A$. dealbata through the evaluation of the total carbon content by elemental analysis $(\mathrm{CHN})$ from a perspective of the possible provision of an ecosystem service by part of a species that is already part of the national landscape, for which the attempts to control and eradicate have been unsuccessful. After determining the average amount of carbon present in the species, the amount of equivalent sequestered carbon dioxide was calculated. By determining the age of the samples collected by dendrometric analysis, the annual productivity of $A$. dealbata in the study region was achieved. Based on these results, the $\mathrm{CO}_{2}$ capture potential for 25 years was projected to analyze the carbon storage potential of the species.

\section{Materials and Methods}

\subsection{Location and A. dealbata Sampling}

For the collection of samples of A. dealbata, was selected Serra da Estrela, more precisely, the parish of União de Freguesias de Vide e Cabeça in the municipality of Seia, as shown in Figure 2. The selection was due to its location in the Serra da Estrela Natural Park, a sensitive area that needs care because it is a protected area, where A. dealbata is proliferating due to the recurrence of rural fires. As presented in Figure 3, several rural fires have overlapped during the last two decades, with several large fires occurring in the study area. As shown, almost the entire territory of the União de Freguesias de Vide e Cabeça has been affected by rural fires. 

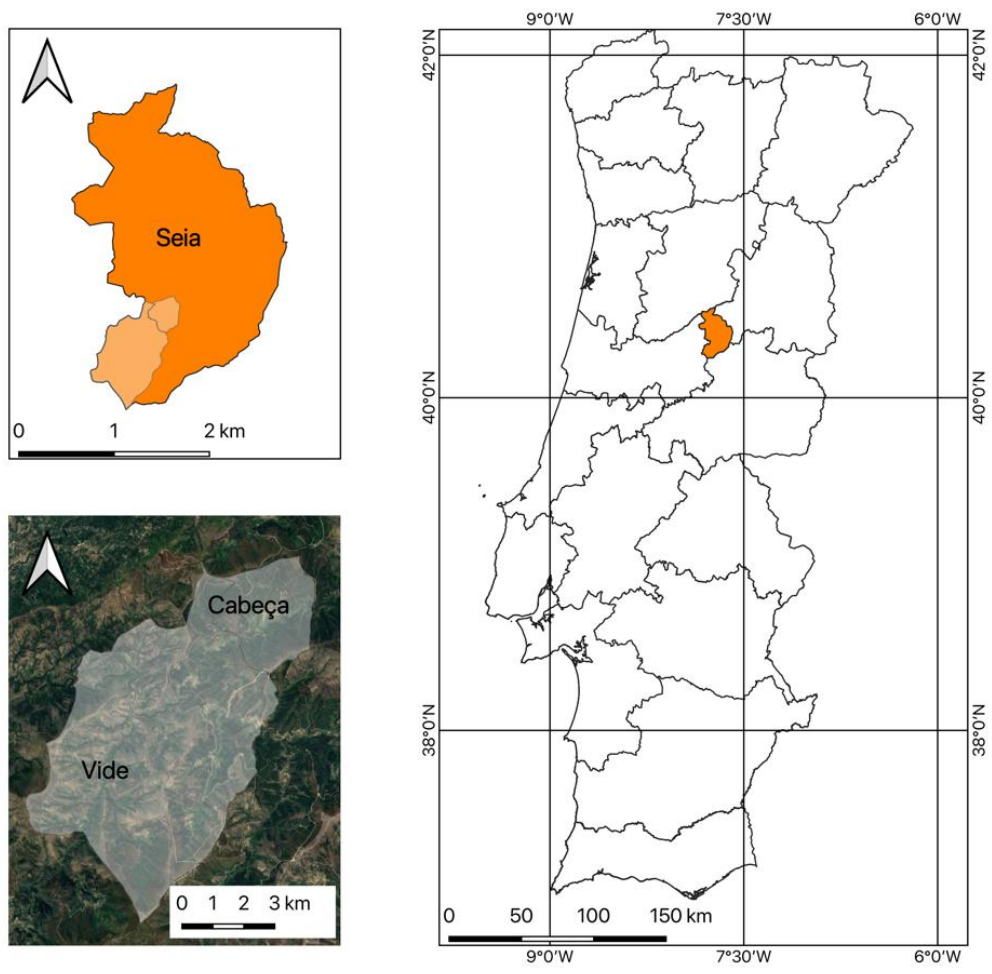

Figure 2. Location of the area under study where the samples of $A$. dealbata were collected.

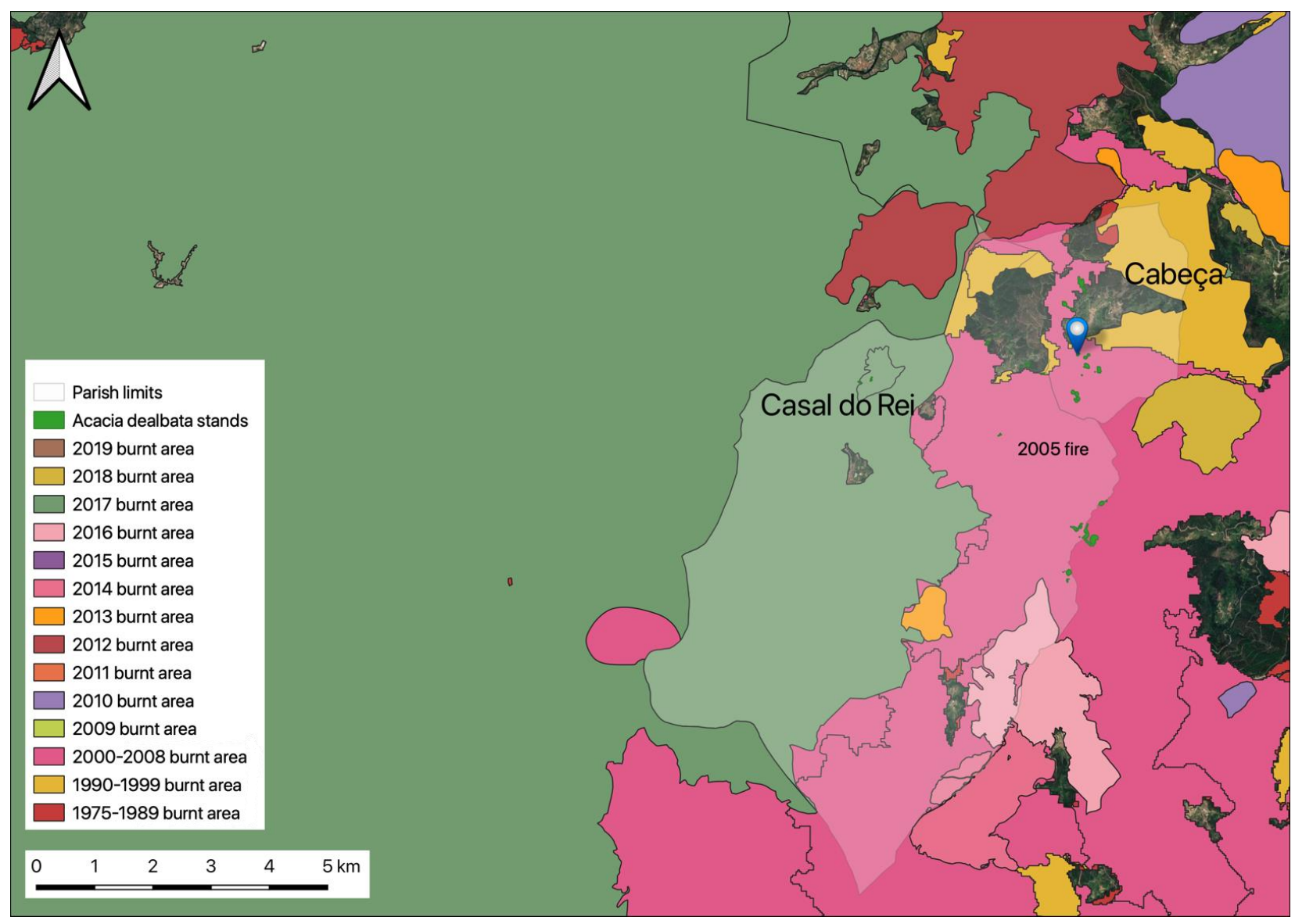

Figure 3. Overlapping occurrences of rural fires during the past two decades in the parish of União de Freguesias de Vide e Cabeça (Seia, Portugal). 
Using open-source geographic information system (GIS) software, QGIS Version 3.16.4 LTR (Chicago, IL, USA), the zones occupied with $A$. dealbata were delimited and the areas estimated. The stand under study is located on the opposite slope of the Ribeira de Loriga valley to the road that connects the village of Casal do Rei to Cabeça, on a hillside that suffered a severe rural fire in 2005. In the post-fire period, A. dealbata gained area, expanding and multiplying the number of stands in the surroundings, as presented in Figure 4.

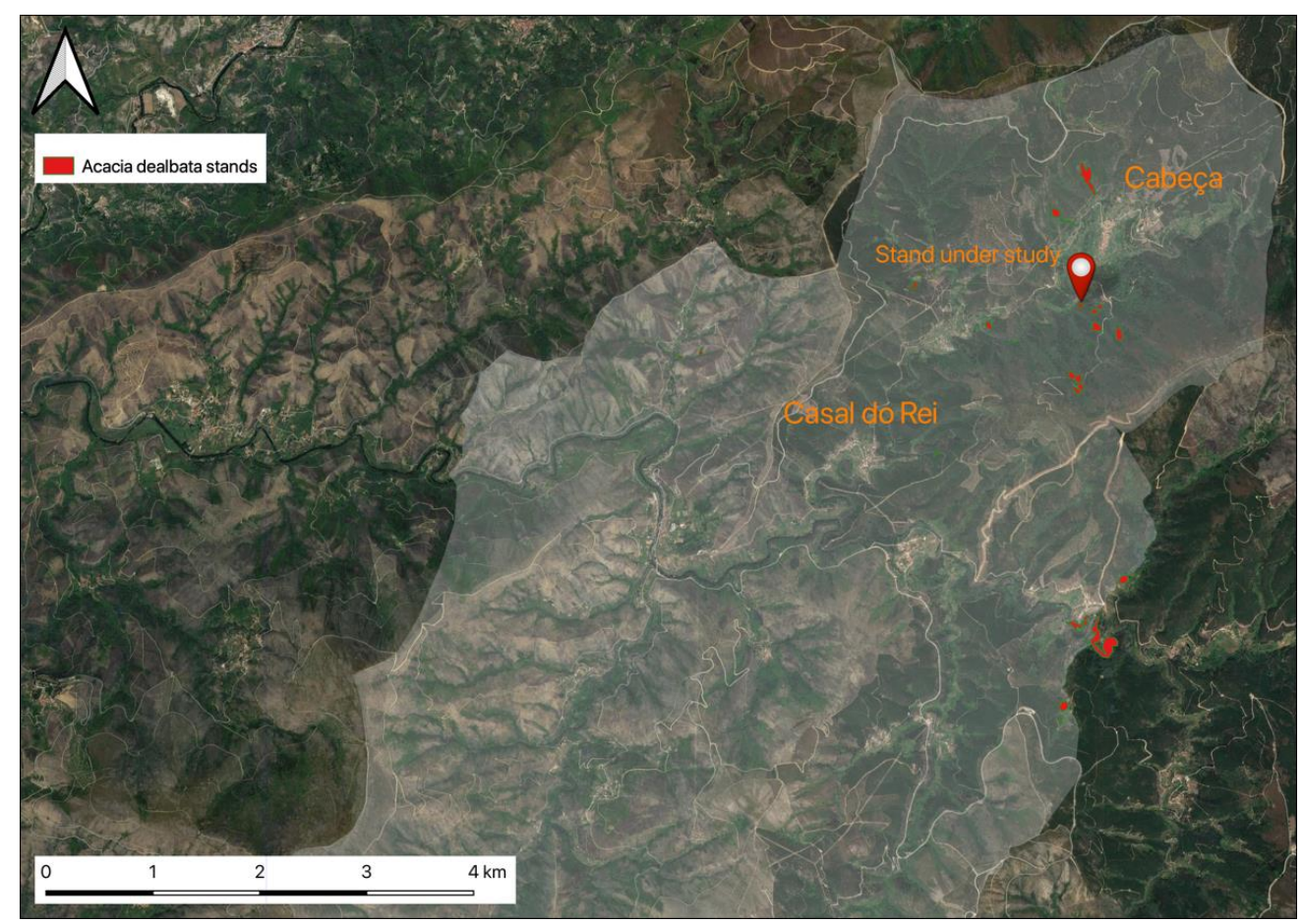

Figure 4. Identification of $A$. dealbata stands (marked in red) in the parish of União de Freguesias de Vide e Cabeça.

Figure 5 shows the areas obtained for the stand selected for this study. This selection was made based on accessibility criteria since the terrain is highly winding with very steep slopes, and pedestrian paths are practically nonexistent. The selected area has approximately $1962 \mathrm{~m}^{2}$, within which a sub-area was around $710 \mathrm{~m}^{2}$, corresponding to a circumference with a radius of $15 \mathrm{~m}$. Subsequently, all trees within this circular zone were identified, and their diameters at breast height (DBHs) were measured. Then, DBHs were distributed by diameter classes: $<5,5-10,10-15,15-20,20-25,25-30,30-35$, and 35-40 cm. This distribution was used to select the trees to be cut for weighing and to measure the total height; the total weight is the sum of the partial weights of the trunk and branches with foliage, and the total height is the sum of the trunk and crown heights. After the selection of the representative elements for each diameter classes, the trees were cut, weighed, and measured as described. A parallel to the ground slice was cut and used to achieve the age of the sample. Only three specimens other than Acacia dealbata were found within this circular area: a specimen of P. pinaster and two specimens of Arbutus unedo L., supporting the idea that it is challenging for other species to develop inside dense acacia stands. 


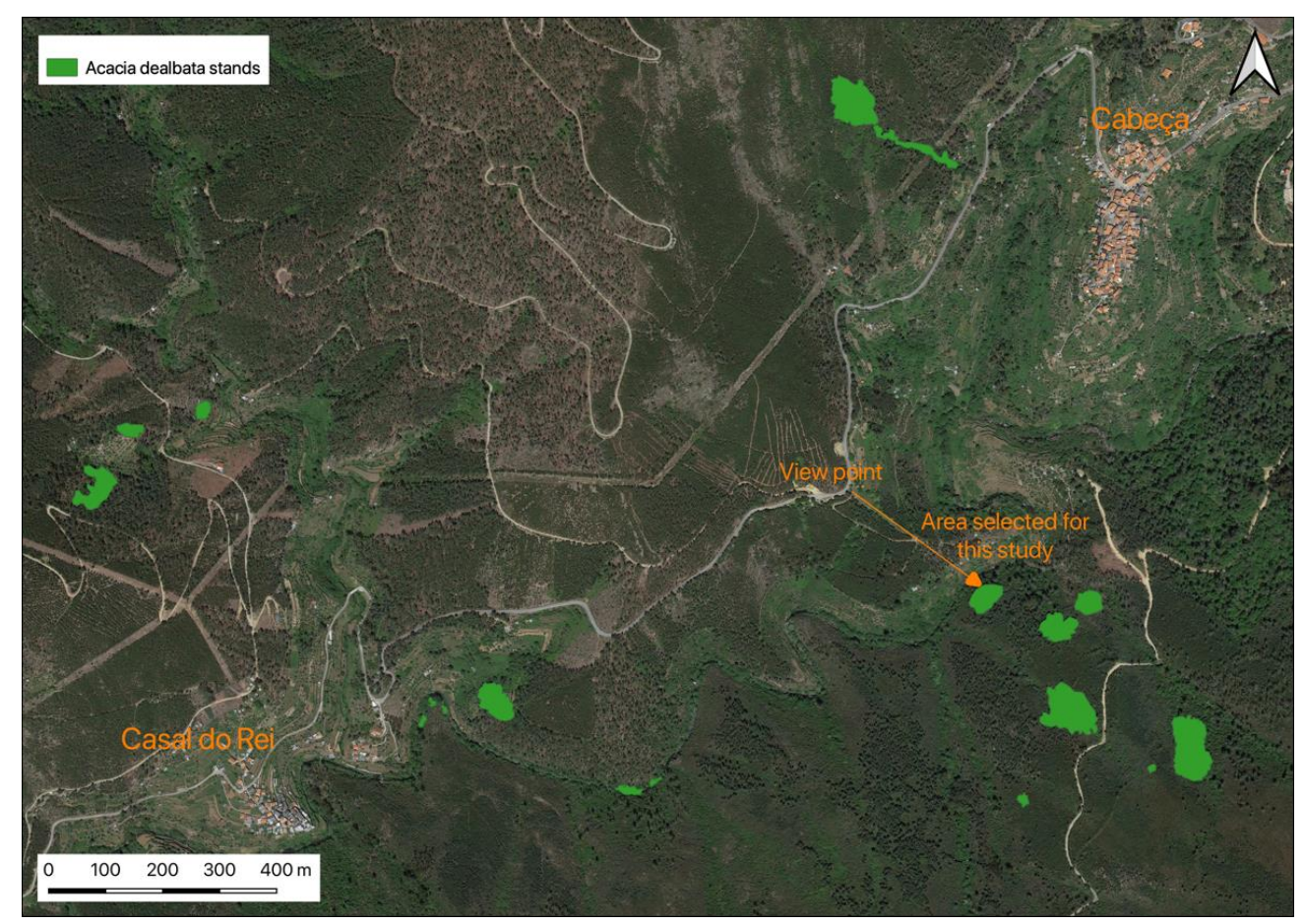

Figure 5. Delimitation and area measurement of the area under study where the samples were collected for elemental and dendrometric analysis.

\subsection{Dendrometric Analysis}

A slice of all the selected trees was cut and distributed to the appropriate DBH category as mentioned above. The samples, cut with a chainsaw, presented many irregularities on the surface, making counting the growth rings difficult. For this reason, they were subjected to an initial sanding to regularize the surface. After, were polished with coarse abrasive sandpaper and finished with fine abrasive sandpaper for a glossy polishing to facilitate observation. Later, the samples were scanned using an HP COLOR LASERJET MFP M477 fdw multifunction printer. The images scanned were treated using the open-source software ImageJ, and the growth rings were counted.

\subsection{Elemental Analysis}

To determine the carbon content, a LECO CHN628 elemental analyzer was used, according to the procedure described in ISO 16948: 2015-Solid biofuels-Determination of total content of carbon, hydrogen, and nitrogen.

\subsection{Determination of the Total Amount of Carbon Weight and Annual Rate of Carbon Storage}

The total amount of carbon storage by a tree can be achieved following the methodology presented by Clark III et al. (1986) and updated by Toochi (2018), which is based on the percentage of total carbon and the moisture content of the tree at the time of cutting $[30,31]$. This methodology is based on four stages and was adapted here as follows:

- $\quad$ Step 1: Determination of the wet weight of aerial biomass

The wet weight was determined using the procedures described in Section 2.3.

- $\quad$ Step 2: Determination of the dry weight of the tree

The dry weight of the tree ( $\left.\mathrm{dw}_{\text {aboveground }}\right)$ was determined by removing the percentage corresponding to the humidity to the total weight.

$$
\mathrm{dw}_{\text {aboveground }}(\mathrm{kg})=(100-\text { moisture }) \times \mathrm{w}_{\text {aboveground }} .
$$

- Step 3: Determination of the carbon weight of the tree 
The carbon weight of the tree was determined by multiplying the carbon content with the dry weight of the tree.

$$
\mathrm{w}_{\text {carbon }}(\mathrm{kg})=\mathrm{C}(\%) \times \mathrm{dw}_{\text {aboveground }}
$$

- $\quad$ Step 4: Determination of the amount of $\mathrm{CO}_{2}$ sequestered in the tree

The amount of $\mathrm{CO}_{2}$ sequestered during the life of the tree is calculated based on the atomic weights of carbon and oxygen, which are, respectively, 12 and 16. The amount of $\mathrm{CO}_{2}$ in the trees is determined by the ratio between the molecular weight of $\mathrm{CO}_{2}$ and the atomic weight of carbon, that is, $(12+2 \times 16) / 12=3.67$. So, to determine the amount and $\mathrm{CO}_{2}$ sequestered by the tree, the calculation is:

$$
\mathrm{w}_{\mathrm{CO} 2}(\mathrm{~kg})=3.67 \times \mathrm{w}_{\text {carbon }} .
$$

- Step 5: Determination of the average amount of $\mathrm{CO}_{2}$ sequestration

The amount of $\mathrm{CO}_{2}$ sequestered annually is calculated by dividing the total weight of $\mathrm{CO}_{2}$ sequestered by the tree and the number of years the tree lives.

\section{Results and Discussion}

The results obtained from the identification of all trees, DBH measurements, and their relative positions to the central point, are shown in Table 1. With the relative location data, it was possible to depict the coverage and distribution of the crowns, as shown in Figure 6.

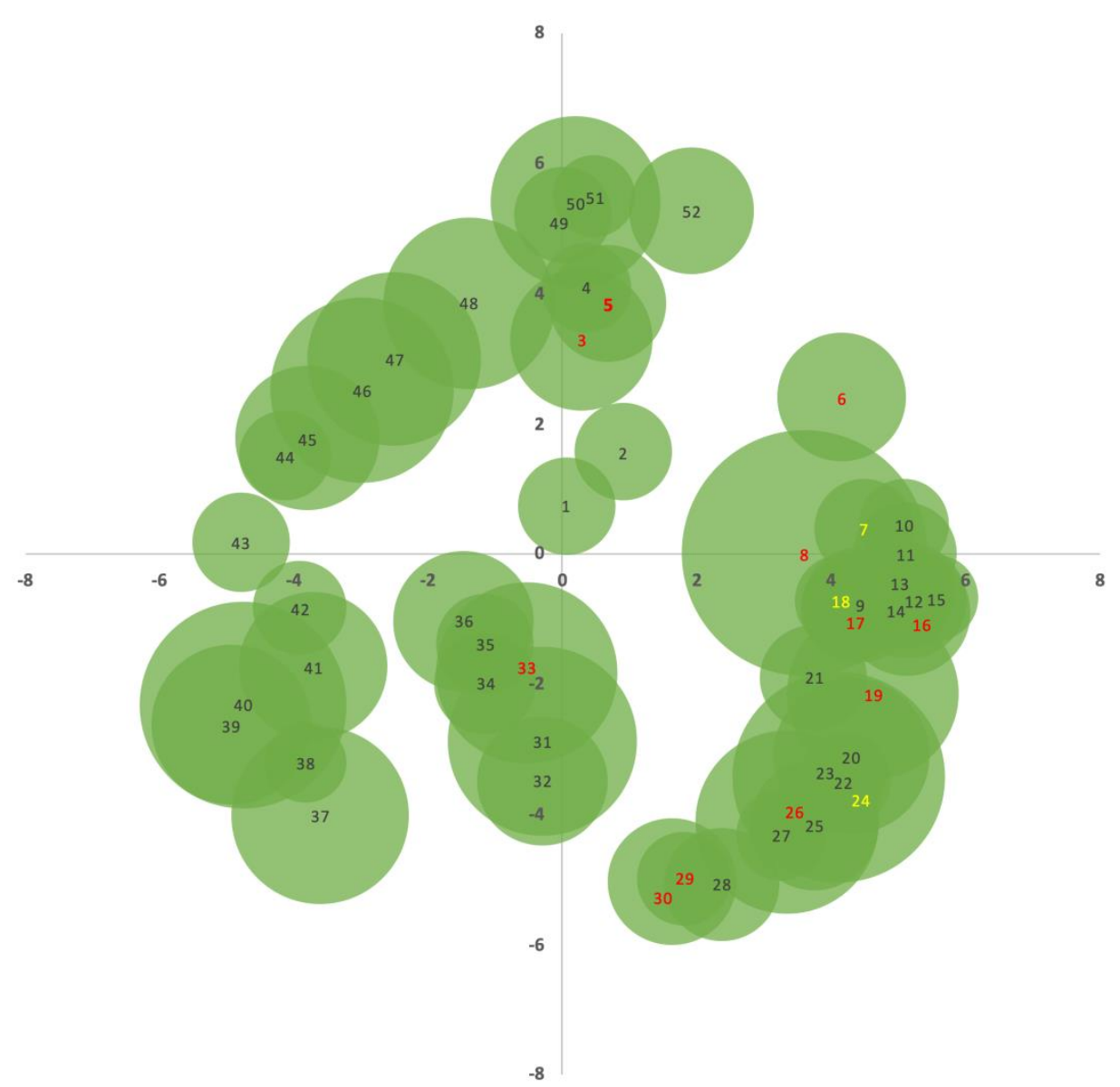

Figure 6. Projection of the A. dealbata crowns within the $15 \mathrm{~m}$ radius selected for the collection of samples. The samples identified in red correspond to those that were cut. Samples 7, 18, and 24, marked in yellow, correspond to the two trees of A. unedo and to the tree of P. pinaster, respectively. 
Table 1. Data collected from the 52 samples that are inside the circumference with a radius of $15 \mathrm{~m}$ (A.d.-A. dealbata; P.p.-P. pinaster; A.u.-A. unedo; $\mathrm{DBH}$-diameter at breast height).

\begin{tabular}{|c|c|c|c|c|c|c|c|c|}
\hline Species & Sample no. & $\begin{array}{c}\text { Distance } \\
\text { (m) }\end{array}$ & $\begin{array}{c}\text { Direction } \\
\left({ }^{\circ}\right)\end{array}$ & $\begin{array}{l}\text { Direction } \\
\quad \text { (rad) }\end{array}$ & $\begin{array}{c}\mathrm{DBH}_{1} \\
(\mathrm{~cm})\end{array}$ & $\begin{array}{c}\mathrm{DBH}_{2} \\
\text { (cm) }\end{array}$ & $\begin{array}{c}\mathrm{DBH}_{\text {average }} \\
\text { (cm) }\end{array}$ & DBH Class \\
\hline A.d. & 1 & 0.73 & 4 & 0.0698 & 4.7 & 4.8 & 4.75 & 5 \\
\hline A.d. & 2 & 1.8 & 30 & 0.5236 & 5 & 4.6 & 4.8 & 5 \\
\hline A.d. & 3 & 3.3 & 5 & 0.0873 & 10.6 & 9.9 & 10.25 & 15 \\
\hline A.d. & 4 & 4.1 & 5 & 0.0873 & 4.4 & 3.7 & 4.05 & 5 \\
\hline A.d. & 5 & 3.9 & 10 & 0.1745 & 7.1 & 6.7 & 6.9 & 10 \\
\hline A.d. & 6 & 4.8 & 60 & 1.0472 & 9.7 & 7.2 & 8.45 & 10 \\
\hline A.u. & 7 & 4.5 & 85 & 1.4835 & & & & \\
\hline A.d. & 8 & 3.6 & 90 & 1.5708 & 30.4 & 31 & 30.7 & 35 \\
\hline A.d. & 9 & 4.5 & 100 & 1.7453 & 6.8 & 6.8 & 6.8 & 10 \\
\hline A.d. & 10 & 5.1 & 85 & 1.4835 & 4.3 & 4.2 & 4.25 & 5 \\
\hline A.d. & 11 & 5.1 & 90 & 1.5708 & 5 & 5.6 & 5.3 & 10 \\
\hline A.d. & 12 & 5.2 & 97 & 1.693 & 4.2 & 4.1 & 4.15 & 5 \\
\hline A.d. & 13 & 5.2 & 98 & 1.7104 & 6.5 & 6.8 & 6.65 & 10 \\
\hline A.d. & 14 & 5.2 & 99 & 1.7279 & 3.5 & 3.5 & 3.5 & 5 \\
\hline A.d. & 15 & 5.6 & 97 & 1.693 & 3.7 & 3.7 & 3.7 & 5 \\
\hline A.d. & 16 & 5.2 & 100 & 1.7453 & 8.1 & 8 & 8.05 & 10 \\
\hline A.d. & 17 & 4.4 & 101 & 1.7628 & 5.4 & 5.6 & 5.5 & 10 \\
\hline A.u. & 18 & 4.2 & 100 & 1.7453 & & & & 5 \\
\hline A.d. & 19 & 5.1 & 115 & 2.0071 & 14.6 & 15.2 & 14.9 & 15 \\
\hline A.d. & 20 & 5.3 & 126 & 2.1991 & 12.5 & 12.2 & 12.35 & 15 \\
\hline A.d. & 21 & 4.2 & 117 & 2.042 & 5.9 & 5.7 & 5.8 & 10 \\
\hline A.d. & 22 & 5.45 & 130 & 2.2689 & 4.6 & 4.5 & 4.55 & 5 \\
\hline A.d. & 23 & 5.4 & 129 & 2.2515 & 3.4 & 3.6 & 3.5 & 5 \\
\hline P.p. & 24 & 5.35 & 130 & 2.2689 & & & & \\
\hline A.d. & 25 & 5.6 & 138 & 2.4086 & 8.2 & 9 & 8.6 & 10 \\
\hline A.d. & 26 & 5.3 & 141 & 2.4609 & 17.4 & 16.7 & 17.05 & 20 \\
\hline A.d. & 27 & 5.4 & 143 & 2.4958 & 4.3 & 4.1 & 4.2 & 5 \\
\hline A.d. & 28 & 5.6 & 155 & 2.7053 & 6.7 & 6.4 & 6.55 & 10 \\
\hline A.d. & 29 & 5.3 & 160 & 2.7925 & 4.4 & 4.5 & 4.45 & 5 \\
\hline A.d. & 30 & 5.3 & 162 & 2.8274 & 8.3 & 8.4 & 8.35 & 10 \\
\hline A.d. & 31 & 2.9 & 186 & 3.2463 & 17.9 & 18.2 & 18.05 & 20 \\
\hline A.d. & 32 & 3.5 & 185 & 3.2289 & 8.5 & 8.4 & 8.45 & 10 \\
\hline A.d. & 33 & 1.9 & 196 & 3.4208 & 16.7 & 16.7 & 16.7 & 20 \\
\hline A.d. & 34 & 2.3 & 210 & 3.6652 & 5.2 & 5.3 & 5.25 & 10 \\
\hline A.d. & 35 & 1.8 & 220 & 3.8397 & 5.2 & 4.7 & 4.95 & 5 \\
\hline A.d. & 36 & 1.8 & 235 & 4.1015 & 10.1 & 10 & 10.05 & 15 \\
\hline A.d. & 37 & 5.4 & 222 & 3.8746 & 16.6 & 15.2 & 15.9 & 20 \\
\hline A.d. & 38 & 5 & 230 & 4.0143 & 3.4 & 3.3 & 3.35 & 5 \\
\hline A.d. & 39 & 5.6 & 242 & 4.2237 & 13 & 13 & 13 & 15 \\
\hline A.d. & 40 & 5.3 & 244 & 4.2586 & 22.2 & 21.6 & 21.9 & 25 \\
\hline A.d. & 41 & 4.1 & 245 & 4.2761 & 11.7 & 10.8 & 11.25 & 15 \\
\hline A.d. & 42 & 4 & 258 & 4.5029 & 4.3 & 4.4 & 4.35 & 5 \\
\hline A.d. & 43 & 4.8 & 272 & 4.7473 & 4.6 & 5.2 & 4.9 & 5 \\
\hline A.d. & 44 & 4.4 & 290 & 5.0615 & 4.5 & 4 & 4.25 & 5 \\
\hline A.d. & 45 & 4.2 & 295 & 5.1487 & 10.8 & 10.2 & 10.5 & 15 \\
\hline A.d. & 46 & 3.9 & 310 & 5.4105 & 16.7 & 17.8 & 17.25 & 20 \\
\hline A.d. & 47 & 3.9 & 320 & 5.5851 & 14.5 & 16.4 & 15.45 & 20 \\
\hline A.d. & 48 & 4.1 & 340 & 5.9341 & 14.2 & 15.6 & 14.9 & 15 \\
\hline A.d. & 49 & 5.2 & 0 & 0 & 4.6 & 4.8 & 4.7 & 5 \\
\hline A.d. & 50 & 5.4 & 2 & 0.0349 & 14.3 & 15.4 & 14.85 & 15 \\
\hline A.d. & 51 & 5.5 & 5 & 0.0873 & 3.6 & 3.2 & 3.4 & 5 \\
\hline A.d. & 52 & 5.6 & 20 & 0.3491 & 7.4 & 8.7 & 8.05 & 10 \\
\hline
\end{tabular}

The DBH was only measured for $A$. dealbata specimens; other identified species were ignored, namely, P. pinaster, with one specimen, and $A$. unedo, with two specimens. In other words, of the 52 trees analyzed, 49 correspond to $A$. dealbata trees. The DBH presented an 
average of $8.97 \pm 1.66 \mathrm{~cm}$, with a minimum of $3.35 \mathrm{~cm}$ in sample 38 and a maximum of $30.7 \mathrm{~cm}$ in sample 8 .

Although the error introduced in measuring the crowns diameters and its shape, which was assumed as being circular, a very clear perception of the arrangement of sets of trees around a larger and older tree was obtained, which was probably responsible for the production of the seeds that gave rise to the others. The 49 specimens of $A$. dealbata in an area of $710 \mathrm{~m}^{2}$ represent a density of 690 trees $\cdot \mathrm{ha}^{-1}$, in line with the normal density of nonplanted forests in Portugal for species such as E. globulus or P. pinaster. Returning to the idea that acacias, especially $A$. dealbata, could be an option for bioenergy production, it may not be as profitable an option as it may appear at first glance. The physico-chemical properties of $A$. dealbata wood, as well as other invasive forest species, such as A. melanoxylon, Robinia pseudoacacia L., and E. globulus, with non-acceptable parameters for the pulp industry, are already well-known. There are several reporting the possibility of using this residual biomass for energy recovery, such as those presented by Sá et al. (2020), Nunes et al. (2020), or Álvarez-Álvarez et al. (2018) [32-34], especially if this recovery is associated to energy densification processes, such as torrefaction or pyrolysis. This seems to be an interesting perspective since even when there is no possibility to use the charcoals for energy purposes, those can be stored in the soil, sequestrating $\mathrm{CO}_{2}$ [35-37]. This possibility, combined with the general idea that $A$. dealbata presents always a fast growth, being therefore a candidate species to be used both in the production of biomass or as a carbon sequestrating agent, in reality, is only valid if some conditions are confirmed, namely the access to sunlight.

The samples were then distributed by the categories established for the DBHs, and selected for cutting, measuring, and weighing, as presented in Table 2. This classification was intended to be as representative as possible of the $49 \mathrm{~A}$. dealbata trees located in the defined area, but also due to accessibility to the tree and capacity to safely collect the samples. Class 5 totalized 19, corresponding to $38.7 \%$ of the $A$. dealbata population, while class 10 counted $28.6 \%$, class 15 counted $18.4 \%$, class 20 counted $10.2 \%$, and classes 25 and 35 counted $0.02 \%$ each. The classes initially defined for 30 and 40 had no specimens.

Table 2. Distribution of samples by DBH classes.

\begin{tabular}{ccc}
\hline DBH Class & Quantity of Trees & $\begin{array}{c}\text { Identification of } \\
\text { Selected Trees }\end{array}$ \\
\hline Class 5 & 19 & $5,17,29$ \\
Class 10 & 14 & $3,6,16,30$ \\
Class 15 & 9 & $19,26,33$ \\
Class 20 & 5 & \\
Class 25 & 1 & 8 \\
Class 35 & 1 & \\
\hline
\end{tabular}

The results of determining the age, carbon content, and the quantity and annual productivity of the collected specimens are shown in Table 3.

Among the selected specimens, the youngest tree (sample no. 5) began its growth in 2013, being 5 years old at the date of the cut, which was carried out in October 2018. The oldest tree was sample no. 8, which started its growth in 1998, which was 20 years at the date of cutting in October 2018. The trees had an average age of $11.63 \pm 2.32$ years. The variance of the determined carbon content values was very small, 0.34 , indicating that the deviations from the sample mean were very small. For this reason, the values are represented by their average, which is $48.85 \pm 0.35 \%$. The sample with the lowest value was sample no. 6, with $48.30 \%$, and the sample with the highest value was sample no. 26, with $50.40 \%$. The highest total weight was sample no. 8 , at $594.8 \mathrm{~kg}$, and the lowest was sample no. 29 , with $4.1 \mathrm{~kg}$. However, the value presented by this sample may be related to the tree being in poor condition, as was under a larger tree that shadowed it. The average total weight measured was $133.40 \pm 103.66 \mathrm{~kg}$. The average annual productivity was 
$9.42 \pm 5.27 \mathrm{~kg} \cdot \mathrm{year}^{-1}$, with the sample no. 8 presenting the highest value, at $30 \mathrm{~kg} \cdot \mathrm{year}^{-1}$, while sample no. 29 presented the lowest value, with $1 \mathrm{~kg} \cdot \mathrm{year}^{-1}$.

Table 3. Weighing the amount of aerial biomass and the annual productivity of the samples collected ( $\mathrm{w}_{\mathrm{w}}$ - trunk weight; $\mathrm{w}_{\text {brl }}$-leaves and branches weight; $\mathrm{w}_{\mathrm{a}}$ - total weight).

\begin{tabular}{|c|c|c|c|c|c|c|c|}
\hline Sample no. & $\begin{array}{c}\text { Growth } \\
\text { Starting Year }\end{array}$ & $\begin{array}{c}\text { Age } \\
\text { (years) }\end{array}$ & $\begin{array}{c}\mathrm{C}_{\text {total }} \\
(\%)\end{array}$ & $\begin{array}{l}w_{w} \\
(k g)\end{array}$ & $\begin{array}{l}w_{\text {brl }} \\
(\mathbf{k g})\end{array}$ & $\begin{array}{c}w_{a} \\
(k g)\end{array}$ & $\begin{array}{l}\text { Productivity } \\
\left(\text { kg } \text { year }^{-1}\right)\end{array}$ \\
\hline 3 & 2008 & 10 & 49.30 & 52.5 & 2.1 & 54.6 & 5 \\
\hline 5 & 2013 & 5 & 48.70 & 23.6 & 5.2 & 28.8 & 6 \\
\hline 6 & 2004 & 14 & 48.30 & 29.7 & 3.8 & 33.5 & 2 \\
\hline 8 & 1998 & 20 & 49.10 & 578.9 & 15.9 & 594.8 & 30 \\
\hline 16 & 2008 & 10 & 48.70 & 45 & 2.8 & 47.8 & 5 \\
\hline 17 & 2009 & 9 & 48.40 & 14.2 & 4.3 & 18.5 & 2 \\
\hline 19 & 2006 & 12 & 48.90 & 145.8 & 21 & 166.8 & 14 \\
\hline 26 & 2004 & 14 & 50.40 & 223.6 & 25.5 & 249.1 & 18 \\
\hline 29 & 2012 & 6 & 48.70 & 3.6 & 0.5 & 4.1 & 1 \\
\hline 30 & 2009 & 9 & 48.80 & 43.5 & 2 & 45.5 & 5 \\
\hline 33 & 2004 & 14 & 48.50 & 205 & 18.9 & 223.9 & 16 \\
\hline
\end{tabular}

The possibility of using fast-growing species, such as those belonging to the genus Acacia, as sources of biomass for energy have been raised by several studies. Gasol et al. (2010) compared acacia species with other short-rotation common Southern European countries crops, such as Italy, from a techno-economic perspective of production viability [38]; Lenis et al. (2013) also studied the use of short-rotation crops for bioenergy with acacias and eucalyptus in Colombia, but focused more on the perspective of the physico-chemical properties of derived fuels and their potential for energy recovery [39]. This dispersion of studies and research work, examples of which can be found in Brazil [40-42], South Africa $[43,44]$, China $[45,46]$, in addition to those already widespread in Europe or the United States of America [47,48], highlights the need for these regions over the past few years to control the dispersion of species belonging to a genus originating mainly from Australia, which has spread to practically all regions of the world, causing serious problems to the local biodiversity, as they enter into direct competition with indigenous species [49].

The high productivity of these species has often been a factor driving their introduction into new habitats, rarely with a prior study of the potential impacts of this introduction. The effects on native species, which start competing for access to nutrients and for area with highly aggressive species, which have developed in very harsh environments with scarcities of water and nutrients, are one example of the research that should be conducted [50]. This type of species, when in the presence of the conditions for its development, presents a fast growth rate, guaranteeing access to nutrients and, especially, to sunlight, without which the growth stall or is reduced to a minimum [4]. It is this heliophilous characteristic that allows them to grow almost exponentially, but it also limits their development from the moment that this access to light is conditioned [51].

In Portugal, several studies have already been carried out on the development of various species of acacias, such as the work presented by Rodríguez-Echeverría et al. (2009) on belowground mutualists and the invasive ability of Acacia longifolia in coastal dunes [52], or the work presented by Santos et al. (2013). Variation in some wood macroscopic properties along the stem of Acacia melanoxylon $\mathrm{R}$. Br. adult trees were noted [53]. With Acacia dealbata being the species with the greatest dissemination in Portugal, Martins et al. (2016) presented forms of invasive alien mapping of Acacia dealbata Link using ASTER multispectral imagery to quickly identify the areas seriously affected by this species [54]. This species has attracted the most attention mainly due to its high rate of [55], but also because of the difficulty that often exists in identifying the problem and in making decisions about the measures to be taken to control and combat it. A recent study by Vaz et al. (2020) assessed stakeholders' perceptions in Northern Portugal about these non-native acacias and their invasion processes, social-ecological impacts, and management, and verified 
the existence of a great lack of knowledge (and experience) regarding the recognition and identification of non-native trees, as well as that on their introduction and invasion history, drivers of dispersion, costs and benefits, and effective management [56].

The results obtained for determining the weight of carbon stored by each of the trees in the sample and the annual rate of carbon sequestration are shown in Table 4.

Table 4. Carbon sequestration per tree and annual rate of carbon sequestration (ARCS, annual rate of carbon sequestration).

\begin{tabular}{cccccccc}
\hline $\begin{array}{c}\text { Sample } \\
\text { no. }\end{array}$ & $\begin{array}{c}\mathbf{C}_{\text {total }} \\
\mathbf{( \% )}\end{array}$ & $\begin{array}{c}\text { Moisture } \\
\text { on Cut } \\
\mathbf{( \% )}\end{array}$ & $\begin{array}{c}\mathbf{w}_{\text {total }} \\
\mathbf{( k g )}\end{array}$ & $\begin{array}{c}\mathbf{d w} \\
\mathbf{( k g )}\end{array}$ & $\begin{array}{c}\mathbf{w}_{\text {carbon }} \\
\mathbf{( k g )}\end{array}$ & $\begin{array}{c}\mathbf{w}_{\mathbf{C O} 2} \\
\mathbf{( k g )}\end{array}$ & $\begin{array}{c}\text { ARCS } \\
(\mathbf{k g} \cdot \mathbf{y e a r} \mathbf{- 1})\end{array}$ \\
\hline 3 & 49.30 & 48.30 & 54.60 & 28.23 & 13.92 & 51.07 & 5.11 \\
5 & 48.70 & 48.65 & 28.80 & 14.79 & 7.20 & 26.43 & 5.29 \\
6 & 48.30 & 42.10 & 33.50 & 19.40 & 9.37 & 34.38 & 2.46 \\
8 & 49.10 & 38.30 & 594.80 & 366.99 & 180.19 & 661.31 & 33.07 \\
16 & 48.70 & 44.12 & 47.80 & 26.71 & 13.01 & 47.74 & 4.77 \\
17 & 48.40 & 39.74 & 18.50 & 11.15 & 5.40 & 19.80 & 2.20 \\
19 & 48.90 & 40.53 & 166.80 & 99.20 & 48.51 & 178.02 & 14.84 \\
26 & 50.40 & 38.56 & 249.10 & 153.05 & 77.14 & 283.09 & 20.22 \\
29 & 48.70 & 36.18 & 4.10 & 2.62 & 1.27 & 4.68 & 0.78 \\
30 & 48.80 & 45.71 & 45.50 & 24.70 & 12.05 & 44.24 & 4.92 \\
33 & 48.50 & 42.78 & 223.90 & 128.12 & 62.14 & 228.04 & 16.29 \\
\hline
\end{tabular}

$\mathrm{w}_{\text {carbon }}$ had an average value of $39.11 \pm 31.54 \mathrm{~kg}$. Sample no. 8 had the highest value, at $180.19 \mathrm{~kg}$, and sample no. 29 had the lowest value, $1.27 \mathrm{~kg} . \mathrm{w}_{\mathrm{CO} 2}$ has an average value of $143.53 \pm 115.76 \mathrm{~kg}$. Sample no. 8 had the highest value, at $661.31 \mathrm{~kg}$, and sample no. 29 had the lowest value, $4.68 \mathrm{~kg}$. The ARCS showed an average value of $9.99 \pm 5.91 \mathrm{~kg} \cdot \mathrm{year}^{-1}$. Sample no. 8 presented the highest value, with $33.07 \mathrm{~kg} \cdot$ year $^{-1}$, and sample no. 29 presented the lowest value, $0.78 \mathrm{~kg} \cdot \mathrm{year}^{-1}$. In reality, this supposed biomass production capacity attributed to A. dealbata only happens in specimens with direct access to sunlight, and this productivity is compromised as soon as one specimen overlaps another, preventing access to direct light, inhibiting its growth and development in the medium and long terms. Figure 7 presents a projection of the carbon sequestration capacity for a period of 25 years based on the values of the annual carbon sequestration rate for each of the samples from the Casal de Rei stand. The calculations with the A. dealbata stand under study in the present work verified that there was no consistency in the results regarding $\mathrm{CO}_{2}$ capture and sequestration capacity, which are directly related to its growth and biomass production. In the analyzed samples, in some cases, the amount of biomass produced appeared to be high. However, in other samples analyzed, this biomass production was very low. This difference in productivity is directly related to its position in the stand, with the distribution shown in Figure 6. 


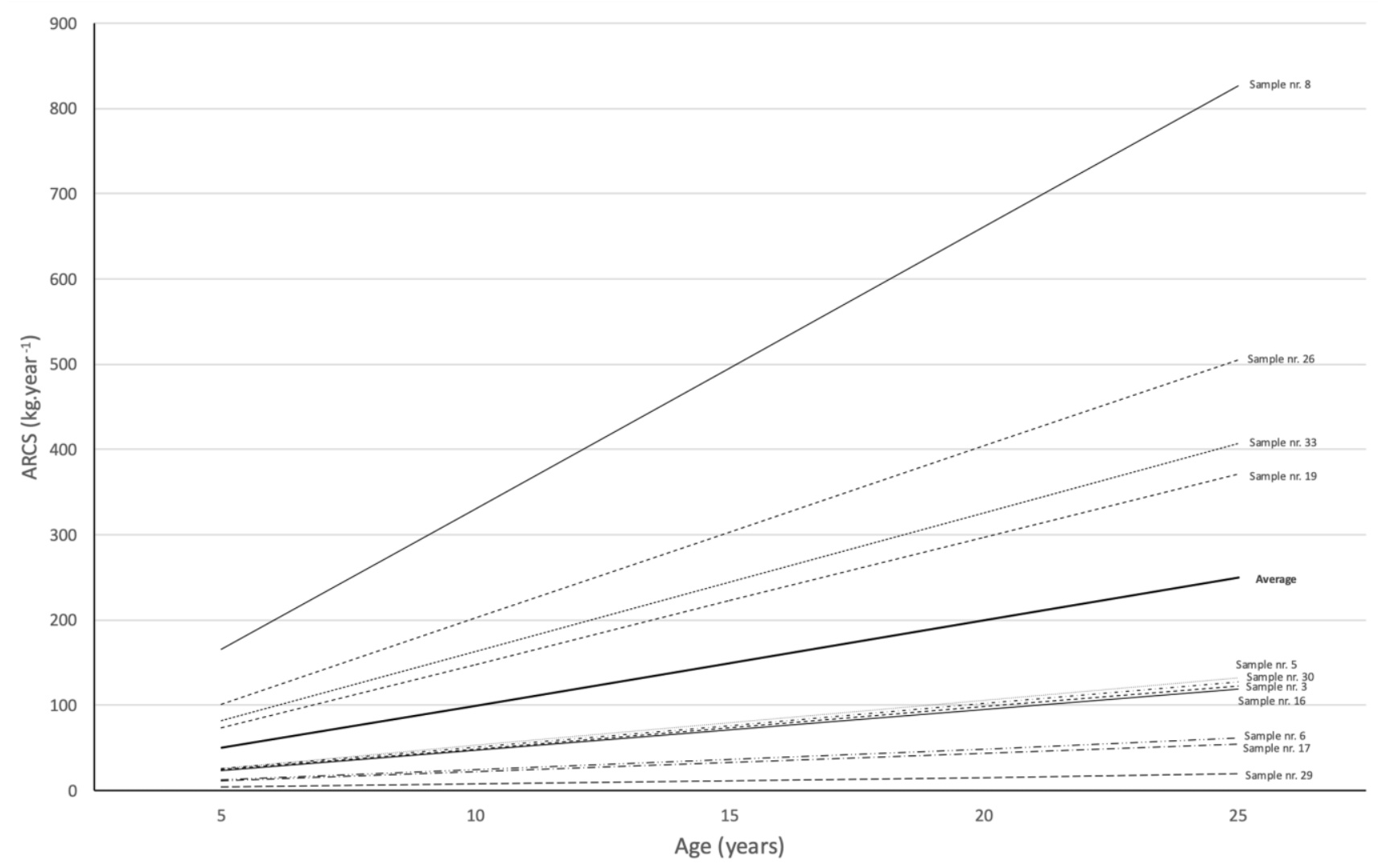

Figure 7. Simulation of carbon sequestration capacity in the medium and long term for A. dealbata.

As can be seen, the four samples (no. 8, 19, 26, and 33) that showed a higher capacity for sequestration, proven by their greater total weight, were those that presented a dominant position in the settlement space and a greater total height. The remaining samples, as can be seen in Figure 6, were located in the vicinity of these or other dominant samples and were therefore considered to be dominated by larger ones. In these cases, the development remained very slow and much lower than that observed for the dominant samples. Thus, was inferred that the use of species such as A. dealbata as a short-rotation energy crop would have to obey spacing criteria that would allow trees to access light, or risk jeopardizing their development in the medium and long terms, although the use of tight calipers in the early developmental stages is common for promoting faster initial growth.

Because this accelerated initial growth may imply a reduction in the quality of the physical and chemical properties of this wood, its use as a fuel in bioenergetic applications, such as the production of wood and wood pellets, does not seem to appear to be feasible from the perspective of using it in short rotation coppice models. However, the energetic valorization of this and other similar species seems to be a possibility to enhance its control and eradication, since, by creating value chains to enable the use to these residual biomasses, it allows the reduction in associated costs and enables the creation of sustainability in the control and eradication processes. The prospect of carbon capture and sequestration through the thermochemical conversion of these residual biomasses provides a new method for mitigating climate change, as previously mentioned, since the carbon captured and sequestered by plants during their lives is stored, for example, in soils or landfills prepared for this purpose.

Nunes et al. (2020) determined the productivity of $17.5 \mathrm{t} \cdot \mathrm{year}^{-1}$, corresponding to a growth after cutting for four years, with all the biomass cut and weighed in two hectares, totaling 140 tons. However, the quality of the biomass presented, all of low diameter, was characterized in terms of its physicochemical properties and used in the production of wood pellets, but did not meet the requirements of quality control standards such as 
ENPlus ${ }^{\circledR}$ [33]. However, as also described by Rodrigues et al. (2018), the properties of several short rotation coppices and some residual biomasses were characterized. The combustibility of some of these biomasses, namely that of $A$. dealbata but also of others, due to the high levels of chlorine and alkali metals, affect the performance of energy recovery equipment when used without any pre-treatment, but significantly improve when undergoing a thermochemical conversion process, in this case, torrefaction [57].

A. dealbata highly dense forests will not produce biomass with sufficient quality for direct energy recovery or to other bio-based uses, mainly due to the heterogeneity of the specimens, although in the first years, are capable of producing a large amount of biomass caused by the intense competition between the shoots. However, this initial fast growth cease when the dominant specimens appear, which inhibiting all others surrounding. Thus, the potential of using this biomass for charcoal production seems to be the most interesting, since it envisages two uses: energy recovery through charcoal, and carbon sequestration. This use can provide an ecosystem service framework for the process of controlling invasive species, which goes beyond preserving biodiversity and reducing the risk of rural fires, as this new aspect can be seen as a mitigating measure for climate change. Other approaches, with different bio-based uses should be considered as well, being a research field with high potential for new developments, e.g., the green chemicals industry.

\section{Conclusions}

Biological invasions are problems that require an integrated approach to their solution, mainly because the complete eradication of the invasive species is not possible, particularly because the species become naturalized and adapt their biological cycles to the invaded ecosystems. This adaptation to local edaphoclimatic conditions the control and eradication of species, in most cases, challenging. The creation of value chains that can minimize the costs associated with operations to control and eradicate invasive species seems to be a method that can contribute to reduce costs associated with these management operations, allowing them to become more sustainable. The possibility of incorporating these biomasses into the supply chains of energy recovery processes is a solution that is already in place in Portugal but can still be further enhanced. However, other possibilities, such as the production of materials with high carbon content, such as charcoal for carbon sequestration, is a possibility that must also be considered since this option can be included in the measures to mitigate climate change. The possibility of using A. dealbata as an energy crop or for the creation of natural carbon sinks with the maintenance of acacia forests does not seem to be an option that justifies the risk of uncontrolled proliferation of the species. Its growing capacity is dependent on factors such as access to sunlight, so the development of dense acacia forests does not present a large ability to capture and sequester carbon in the medium and long terms. Otherwise, these dense forests may potentiate other risks, such as the occurrence of rural fires, due to the increased accumulation of biomass, but mainly due to the loss of biodiversity in this type of stands.

Author Contributions: Conceptualization, L.J.R.N. and C.I.R.M.; methodology, L.J.R.N., N.M.C.A.R. and C.J.P.G.; validation, L.J.R.N., M.A.M.R. and C.J.P.G.; formal analysis, L.J.R.N., C.I.R.M. and M.A.M.R.; investigation, L.J.R.N., M.A.M.R., C.I.R.M., C.J.P.G. and N.M.C.A.R.; resources, L.J.R.N.; data curation, L.J.R.N., M.A.M.R. and C.I.R.M.; writing—original draft preparation, L.J.R.N., M.A.M.R. and C.I.R.M.; writing-review and editing, L.J.R.N., M.A.M.R., C.I.R.M., C.J.P.G. and N.M.C.A.R.; supervision, N.M.C.A.R. and C.J.P.G.; project administration, N.M.C.A.R. and C.J.P.G. All authors have read and agreed to the published version of the manuscript.

Funding: L.J.R.N. was supported by proMetheus-Research Unit on Energy, Materials and Environment for Sustainability-UIDP/05975/2020, funded by national funds through Fundação para a Ciência e Tecnologia (FCT).

Institutional Review Board Statement: Not applicable.

Informed Consent Statement: Not applicable. 
Data Availability Statement: The data presented in this study are available on request from the corresponding author. The data are not publicly available due to the fact that the research has not yet concluded, and the data will be updated.

Acknowledgments: The authors would like to thank the group of forest sappers from Manteigas for their support in opening access to the site under study, and the União de Freguesias de Vide e Cabeça for their support during the entire investigation.

Conflicts of Interest: The authors declare no conflict of interest.

\section{References}

1. Sanderson, L.A.; McLaughlin, J.A.; Antunes, P.M. The last great forest: A review of the status of invasive species in the North American boreal forest. Forestry 2012, 85, 329-340. [CrossRef]

2. Allen, E.B.; Steers, R.J.; Dickens, S.J. Impacts of Fire and Invasive Species on Desert Soil Ecology. Rangel. Ecol. Manag. 2011, 64, 450-462. [CrossRef]

3. Courchamp, F.; Caut, S.; Bonnaud, E.; Bourgeois, K.; Angulo, E.; Watari, Y. Eradication of alien invasive species: Surprise effects and conservation successes. Island Invasives 2011, 1, 285-289.

4. Midgley, G.F.; Rutherford, M.C.; Davis, G.W.; Bosenberg, J.D.W. Photosynthetic Responses of Heliophilous Rhus Species to Environmental Modification by Invasive Shrubs. Funct. Ecol. 1992, 6, 334. [CrossRef]

5. González-Muñoz, N.; Costa-Tenorio, M.; Espigares, T. Invasion of alien Acacia dealbata on Spanish Quercus robur forests: Impact on soils and vegetation. For. Ecol. Manag. 2012, 269, 214-221. [CrossRef]

6. Barbero, M.; Bonin, G.; Loisel, R. Changes and disturbances of forest ecosystems caused by human activities in the western part of the mediterranean basin. Vegetatio 1990, 87, 151-173. [CrossRef]

7. Brunel, S.; Schrader, G.; Brundu, G.; Fried, G. Emerging invasive alien plants for the Mediterranean Basin. EPPO Bull. 2010, 40, 219-238. [CrossRef]

8. Hunt, M.A.; Battaglia, M.; Davidson, N.J.; Unwin, G.L. Competition between plantation Eucalyptus nitens and Acacia dealbata weeds in northeastern Tasmania. For. Ecol. Manag. 2006, 233, 260-274. [CrossRef]

9. Bi, H.; Turvey, N. Inter-Specific Competition between Seedlings of Pinus radiata, Eucalyptus regnans and Acacia melanoxylon. Aust. J. Bot. 1994, 42, 61-70. [CrossRef]

10. Forrester, D.I.; Bauhus, J.; Cowie, A.L. On the success and failure of mixed-species tree plantations: Lessons learned from a model system of Eucalyptus globulus and Acacia mearnsii. For. Ecol. Manag. 2005, 209, 147-155. [CrossRef]

11. Bouillet, J.-P.; Laclau, J.-P.; Gonçalves, J.L.D.M.; Voigtlaender, M.; Gava, J.L.; Leite, F.P.; Hakamada, R.; Mareschal, L.; Mabiala, A.; Tardy, F.; et al. Eucalyptus and Acacia tree growth over entire rotation in single- and mixed-species plantations across five sites in Brazil and Congo. For. Ecol. Manag. 2013, 301, 89-101. [CrossRef]

12. Correia, M.; Castro, S.; Ferrero, V.; Crisóstomo, J.A.; Rodríguez-Echeverría, S. Reproductive biology and success of invasive Australian acacias in Portugal. Bot. J. Linn. Soc. 2014, 174, 574-588. [CrossRef]

13. Duarte, L.N.; Gomes, C.P.; Marchante, H.; Marchante, E. Integrating knowledge of ecological succession into invasive alien plant management: A case study from Portugal. Appl. Veg. Sci. 2020, 23, 328-339. [CrossRef]

14. Le Maitre, D.C.; Kotzee, I.M.; O'Farrell, P.J. Impacts of land-cover change on the water flow regulation ecosystem service: Invasive alien plants, fire and their policy implications. Land Use Policy 2014, 36, 171-181. [CrossRef]

15. Moreira, F.; Ferreira, A.; Abrantes, N.; Catry, F.; Fernandes, P.; Roxo, L.; Keizer, J.; Silva, J. Occurrence of native and exotic invasive trees in burned pine and eucalypt plantations: Implications for post-fire forest conversion. Ecol. Eng. 2013, 58, 296-302. [CrossRef]

16. Aran, D.; García-Duro, J.; Reyes, O.; Casal, M. Fire and invasive species: Modifications in the germination potential of Acacia melanoxylon, Conyza canadensis and Eucalyptus globulus. For. Ecol. Manag. 2013, 302, 7-13. [CrossRef]

17. Fernandes, M.M.; Devy-Vareta, N.; Rangan, H. Plantas exóticas invasoras e instrumentos de gestão territorial. O caso paradigmático do género Acacia em Portugal. GOT J. Geogr. Spat. Plan. 2013, 4, 83-107. [CrossRef]

18. Ferreira, S.; Monteiro, E.; Brito, P.; Vilarinho, C. Biomass resources in Portugal: Current status and prospects. Renew. Sustain. Energy Rev. 2017, 78, 1221-1235. [CrossRef]

19. Briones-Hidrovo, A.; Copa, J.; Tarelho, L.A.; Gonçalves, C.; da Costa, T.P.; Dias, A.C. Environmental and energy performance of residual forest biomass for electricity generation: Gasification vs. combustion. J. Clean. Prod. 2021, 289, 125680. [CrossRef]

20. Richardson, D.M.; Pysek, P.; Rejmanek, M.; Barbour, M.G.; Panetta, F.D.; West, C.J. Naturalization and invasion of alien plants: Concepts and definitions. Divers. Distrib. 2000, 6, 93-107. [CrossRef]

21. Pyšek, P.; Richardson, D.M. The biogeography of naturalization in alien plants. J. Biogeogr. 2006, 33, 2040-2050. [CrossRef]

22. Águas, A.; Larcombe, M.J.; Matias, H.; Deus, E.; Potts, B.M.; Rego, F.C.; Silva, J.S. Understanding the naturalization of Eucalyptus globulus in Portugal: A comparison with Australian plantations. Eur. J. For. Res. 2017, 136, 433-446. [CrossRef]

23. Lorenzo, P.; Gonzalez, L.O.; Reigosa, M.J. The genus Acacia as invader: The characteristic case of Acacia dealbata Link in Europe. Ann. For. Sci. 2010, 67, 101. [CrossRef]

24. La Mantia, T.; Pasta, S.; Badalamenti, E. Acacia cyclops A. Cunn. ex G. Don (Leguminosae) in Italy: First cases of naturalization. An. Jardín Botánico Madr. 2012, 69, 193-200. [CrossRef] 
25. Rouget, M.; Richardson, D.M. Inferring Process from Pattern in Plant Invasions: A Semimechanistic Model Incorporating Propagule Pressure and Environmental Factors. Am. Nat. 2003, 162, 713-724. [CrossRef] [PubMed]

26. Richardson, D.M.; Hui, C.; Nuñez, M.A.; Pauchard, A. Tree invasions: Patterns, processes, challenges and opportunities. Biol. Invasions 2014, 16, 473-481. [CrossRef]

27. Peltzer, D.A.; Allen, R.B.; Lovett, G.; Whitehead, D.; Wardle, D.A. Effects of biological invasions on forest carbon sequestration. Glob. Chang. Biol. 2010, 16, 732-746. [CrossRef]

28. Feng, Q.; Wang, B.; Chen, M.; Wu, P.; Lee, X.; Xing, Y. Invasive plants as potential sustainable feedstocks for biochar production and multiple applications: A review. Resour. Conserv. Recycl. 2021, 164, 105204. [CrossRef]

29. Rogelj, J.; Shindell, D.; Jiang, K.; Fifita, S.; Forster, P.; Ginzburg, V.; Handa, C.; Kheshgi, H.; Kobayashi, S.; Kriegler, E. Mitigation pathways compatible with $1.5^{\circ} \mathrm{C}$ in the context of sustainable development. In Global Warming of $1.5^{\circ} \mathrm{C}$; Intergovernmental Panel on Climate Change (IPCC): Geneva, Switzerland, 2018; pp. 93-174.

30. Toochi, E.C. Carbon sequestration: How much can forestry sequester $\mathrm{CO}_{2}$ ? For. Res. Eng. Int. J. 2018, 2, 148-150. [CrossRef]

31. Clark, A.; Saucier, J.R.; McNab, W.H. Total-Tree Weight, Stem Weight and Volume Tables for Hardwood Species in the Southeast; Research Division; Georgia Forestry Commission: Milledgeville, GA, USA, 1986.

32. Sá, L.C.R.; Loureiro, L.M.E.F.; Nunes, L.J.R.; Mendes, A.M. Torrefaction as a Pretreatment Technology for Chlorine Elimination from Biomass: A Case Study Using Eucalyptus globulus Labill. Resources 2020, 9, 54. [CrossRef]

33. Nunes, L.J.; Raposo, M.A.; Meireles, C.I.; Gomes, C.J.P.; Ribeiro, N.M.A. Control of Invasive Forest Species through the Creation of a Value Chain: Acacia dealbata Biomass Recovery. Environments 2020, 7, 39. [CrossRef]

34. Álvarez-Álvarez, P.; Pizarro, C.; Barrio-Anta, M.; Cámara-Obregón, A.; Bueno, J.L.M.; Álvarez, A.; Gutiérrez, I.; Burslem, D.F. Evaluation of Tree Species for Biomass Energy Production in Northwest Spain. Forests 2018, 9, 160. [CrossRef]

35. Lorenz, K.; Lal, R. Biochar application to soil for climate change mitigation by soil organic carbon sequestration. J. Plant Nutr. Soil Sci. 2014, 177, 651-670. [CrossRef]

36. Stewart, C.E.; Zheng, J.; Botte, J.; Cotrufo, M.F. Co-generated fast pyrolysis biochar mitigates green-house gas emissions and increases carbon sequestration in temperate soils. GCB Bioenergy 2012, 5, 153-164. [CrossRef]

37. Matovic, D. Biochar as a viable carbon sequestration option: Global and Canadian perspective. Energy 2011, 36, 2011-2016. [CrossRef]

38. Gasol, C.M.; Brun, F.; Mosso, A.; Rieradevall, J.; Gabarrell, X.; Durany, X.G. Economic assessment and comparison of acacia energy crop with annual traditional crops in Southern Europe. Energy Policy 2010, 38, 592-597. [CrossRef]

39. Lenis, Y.A.; Osorio, L.F.; Pérez, J.F. Fixed Bed Gasification of Wood Species with Potential as Energy Crops in Colombia: The Effect of the Physicochemical Properties. Energy Sources Part A Recover. Util. Environ. Eff. 2013, 35, 1608-1617. [CrossRef]

40. Caldeira, M.; Saidelles, F.; Schumacher, M.; Godinho, T.D.O. Biomass in Acacia mearnsii De Wild stand, Rio Grande do Sul, Brasil. Sci. For. 2011, 39, 133-141.

41. Acuña, E.; Cancino, J.; Rubilar, R.; Sandoval, S. Aboveground Biomass Growth and Yield of First Rotation Cutting Cycle of Acacia and Eucalyptus Short Rotation Dendroenergy Crops. Rev. Árvore 2017, 41, 41. [CrossRef]

42. de Souza, J.B.; de Azevêdo, T.K.B.; Sousa, T.B.; da Silva, G.G.C.; Guimarães, J.B., Jr.; Pimenta, A.S. Colagem de compensados com adesivo à base de taninos de Acacia mangium Wild. cultivada no Nordeste do Brasil. Rev. Bras. Ciências Agrárias (Agrária) 2020, 15,8659 .

43. Jing, Q.; Conijn, S.J.; Jongschaap, R.E.; Bindraban, P.S. Modeling the productivity of energy crops in different agro-ecological environments. Biomass Bioenergy 2012, 46, 618-633. [CrossRef]

44. Richardson, D.M.; Kluge, R.L. Seed banks of invasive Australian Acacia species in South Africa: Role in invasiveness and options for management. Perspect. Plant Ecol. Evol. Syst. 2008, 10, 161-177. [CrossRef]

45. Zhang, H.; Guan, D.; Song, M. Biomass and carbon storage of Eucalyptus and Acacia plantations in the Pearl River Delta, South China. For. Ecol. Manag. 2012, 277, 90-97. [CrossRef]

46. Na, W.; Molong, S.; Lihai, W. Comparative Analysis on Calorific Value of Eucalyptus, Acacia mangium and Acacia crassicarpa. For. Eng. 2011, 4, 23-30.

47. Feledyn-Szewczyk, B.; Matyka, M.; Staniak, M. Comparison of the Effect of Perennial Energy Crops and Agricultural Crops on Weed Flora Diversity. Agronomy 2019, 9, 695. [CrossRef]

48. Sartori, F.; Lal, R.; Ebinger, M.H.; Parrish, D.J. Potential Soil Carbon Sequestration and CO2Offset by Dedicated Energy Crops in the USA. Crit. Rev. Plant Sci. 2006, 25, 441-472. [CrossRef]

49. Chornesky, E.A.; Bartuska, A.M.; Aplet, G.H.; Britton, K.O.; Cummings-Carlson, J.; Davis, F.W.; Eskow, J.; Gordon, D.R.; Gottschalk, K.W.; Haack, R.A.; et al. Science Priorities for Reducing the Threat of Invasive Species to Sustainable Forestry. Bioscience 2005, 55, 335-348. [CrossRef]

50. Yemshanov, D.; McKenney, D.W.; Pedlar, J.H.; Koch, F.H.; Cook, D. Towards an integrated approach to modelling the risks and impacts of invasive forest species. Environ. Rev. 2009, 17, 163-178. [CrossRef]

51. Lubalega, T.K.; Gbawe, V.; KHASA, D.P.; RUEL, J.-C.; LEJOLY, J. Forest Regeneration of the Bateke Plateau Savannahs from Acacia Auriculformis Plantations in the Democratic Republic of the Congo. Forest 2017, 13, 21-30.

52. Rodríguez-Echeverría, S.; Crisóstomo, J.A.; Nabais, C.; Freitas, H. Belowground mutualists and the invasive ability of Acacia longifolia in coastal dunes of Portugal. Biol. Invasions 2009, 11, 651-661. [CrossRef] 
53. Santos, A.; Simoes, R.; Tavares, M.L.C. Variation of some wood macroscopic properties along the stem of Acacia melanoxylon R. Br. adult trees in Portugal. For. Syst. 2013, 22, 463-470. [CrossRef]

54. Martins, F.; Alegria, C.; Artur, G. Mapping invasive alien Acacia dealbata Link using ASTER multispectral imagery: A case study in central-eastern of Portugal. For. Syst. 2016, 25, e078. [CrossRef]

55. Nunes, L.J.R.; Meireles, C.I.R.; Gomes, C.J.P.; Ribeiro, N.M.C.A. Historical Development of the Portuguese Forest: The Introduction of Invasive Species. Forests 2019, 10, 974. [CrossRef]

56. Vaz, A.S.; Ribeiro, J.; Honrado, J.P.; Vicente, J.R. Stakeholders' perceptions towards non-native acacias and implications for their management in Portugal. Forestry 2019, 93, 557-566. [CrossRef]

57. Rodrigues, A.; Loureiro, L.; Nunes, L. Torrefaction of woody biomasses from poplar SRC and Portuguese roundwood: Properties of torrefied products. Biomass Bioenergy 2018, 108, 55-65. [CrossRef] 